\title{
Factors influencing length of hospital stay in patients with diabetic foot ulcers
}

\author{
Analiza factorilor ce influențează durata spitalizării la pacienții cu ulcerații \\ ale piciorului diabetic
}

\author{
George NIȚA ${ }^{1}$, Andreea GHERASIM², Otilia NIȚĂ${ }^{2}$, Alina Delia POPA ${ }^{3}$, Lidia Iuliana ARHIRE ${ }^{2}$, \\ Laura MIHALACHE ${ }^{2}$, Mariana GRAUR ${ }^{1}$ \\ ${ }^{1}$ Universitatea de Medicină şi Farmacie „Grigore T. Popa“, Iași, România \\ ${ }^{2}$ Departamentul Diabet, Nutriţie şi Boli Metabolice, Facultatea de Medicină, Universitatea de Medicină şi \\ Farmacie „Grigore T. Popa“, Iași, România \\ ${ }^{3}$ Departamentul Nursing, Facultatea de Medicină, Universitatea de Medicină şi Farmacie „Grigore T. Popa“, \\ lași, România
}

\begin{abstract}
Diabetic foot represents the consequence of changes caused by diabetes in the foot, meaning an association of infection, ulceration and / or destruction of deep tissues with neuropathy and peripheral vascular disease in the foot, below the ankle. The aim of the study was to evaluate the factors that may influence the length of hospital stay in patients with diabetic foot ulcers.

Material and methods. An observational study was performed on a sample of patients hospitalized in the Diabetes, Nutrition and Metabolic Diseases Clinic within "St. Spiridon" County Emergency Clinical Hospital, Iași, between 01.01.2007 and 31.12.2017. Sociodemographic characteristics of the patients, history of the disease, biological parameters, duration of hospitalization were registered in a database. Severity of foot ulcerations was quantified using the San Elian Wound Scoring System (SEWSS). The relationships between length of hospital stay, severity of ulceration, biological parameters and complications of diabetes were analyzed.

Results. The average length of hospital stay in the studied group was $19.68 \pm 13.38$ days. When analyzing the correlation between length of hospital stay and inflammatory parameters, we found that it correlated positively with white blood cells, neutrophils (PMN), C-reactive protein (CRP) and negatively with hemoglobin, hematocrit, total proteins, alkaline reserve and sideremia. Assessment of the severity of ulcerations using SEWSS (mild, moderate and severe) revealed a percentage of $85.7 \%$ of cases with moderate grade ulcers, and $9 \%$ of cases having severe grade ulcers. Severity of ulcerations correlated inversely with hemoglobin, hematocrit, total proteins and sideremia. Direct correlations were found between the severity score and the following parameters: white blood cells, PMN, fibrinogen, CRP. The length of hospital stay was significantly correlated with the severity of ulceration assessed by the SEWSS $(r=0.272, p<0.001)$.

Conclusions. Admission in the hospital with more severe ulcerations has been associated with increased length of hospital stay, thus suggesting the need for patient education and active screening of the diabetic foot.
\end{abstract}

Keywords: diabetic foot, diabetes, predictor, length of hospital stay 


\begin{abstract}
REZUMAT
Piciorul diabetic reprezintă consecința modificărilor determinate de diabetul zaharat la nivelul piciorului, adică asocierea infecției, ulcerației şi/sau distrucțiilor țesuturilor profunde cu neuropatie şi cu boală vasculară periferică în diferite grade, la nivelul piciorului, mai jos de gleznă. Scopul studiului a fost evaluarea factorilor care pot influența durata spitalizării pacienților internați pentru ulcerații ale piciorului diabetic.

Material și metode. S-a realizat un studiu observațional pe un eșantion de pacienți spitalizați în Clinica Diabet, Nutriție și Boli Metabolice din cadrul Spitalului Clinic Județean de Urgență "Sf. Spiridon", Iași, în perioada 01.01.2007 - 31.12.2017. S-au înregistrat într-o bază de date caracteristicile sociodemografice ale pacienților, istoricul bolii, parametrii biologici la internare, durata de spitalizare. Severitatea ulcerațiilor membrelor inferioare s-a cuantificat cu ajutorul sistemului San Elian de Scorare al Ulcerațiilor (SEWSS). $S$-au analizat relațiile dintre durata de spitalizare, severitatea ulcerației, parametrii biologici și complicațiile diabetului zaharat.

Rezultate. Durata medie de spitalizare în lotul studiat a fost de 19,68 $\pm 13,38$ zile. Analiza corelației între durata spitalizării și parametrii inflamatori a relevat faptul că aceasta s-a corelat pozitiv cu globulele albe, neutrofilele (PMN), proteina C reactivă (CRP) și negativ cu hemoglobina $(\mathrm{Hb})$, hematocritul $(\mathrm{Ht})$, proteinele totale, rezerva alcalină și sideremia. Evaluarea severității ulcerațiilor cu ajutorul SEWSS (ușoară, moderată și severă), a relevat un procent de $85,7 \%$ cazuri cu grad moderat și 9\% cazuri cu grad sever. Severitatea ulcerațiilor s-a corelat invers cu hemoglobina, hematocritul, proteinele totale și sideremia și direct cu următorii parametri: leucocite, $P M N$, fibrinogen, CRP. Durata spitalizării s-a corelat semnificativ cu gradarea realizată de scorul SEWSS $(r=0,272, p<0,001)$.

Concluzii. Adresarea la internare in stadii lezionale avansate s-a asociat cu creșterea duratei de spitalizare, sugerând astfel necesitatea educației pacienților și a screening-ului activ al piciorului diabetic.
\end{abstract}

Cuvinte cheie: picior diabetic, diabet zaharat, predictor, durata spitalizării

\section{INTRODUCERE}

Creșterea numărului și gravității complicațiilor diabetului zaharat (DZ) este atribuită factorilor de risc individuali, sărăciei, diferențelor rasiale și etnice, precum și calității sistemelor de sănătate. Piciorul diabetic reprezintă o complicație cronică specifică frecvent corelată din punct de vedere patogenic cu polineuropatia și boala arterială periferică. Studiile efectuate arată că aproximativ $25 \%$ dintre pacienții cu DZ vor dezvolta complicații la nivelul picioarelor în cursul evoluției bolii [1]. După Boulton, aproximativ 15\% dintre pacienți vor suferi o ulcerație a piciorului și $12-24 \%$ vor necesita amputații [2]. Dintre toate amputațiile la pacienții cu DZ, 85\% sunt precedate de o ulcerație a piciorului care, ulterior, se deteriorează până la gangrenă severă [3], ceea ce arată necesitatea diagnosticului precoce. Apelqvist și colab. au observat un lot de pacienți de la prezentarea la medic pentru un ulcer al piciorului și până la vindecare [4], remarcând că la $27 \%$ dintre pacienți durata până la vindecare a fost mai mare de 5 luni, la $19 \%$ a durat 3-4 luni, iar la $54 \%$ a fost sub 2 luni. Amputația membrelor inferioare a fost necesară la $24 \%$ dintre pacienți, la un cost mediu de 44.790 USD, în timp ce la pacienții tratați medical costul mediu a fost de 6.664 USD. Proporția cheltuielilor din totalul costurilor legate de spitalizare a fost de $39 \%$ în rândul pacienților cu ulcer și de 82\% în rândul persoanelor amputate [4]. Prevenirea și tratarea suferințelor piciorului diabetic este indispensabilă pentru a reduce impactul negativ asupra calității vieții pacienților și povara economică asociată asupra sistemului de sănătate [5]. Un rol important în producerea leziunilor îl au traumele habituale produse de încălțăminte, micozele cutanate și ale unghiilor, limitarea mobilității articulare, gradul de activitate al pacienților și disfuncționalitățile din sistemul de asistență medicală. Prevenirea și tratamentul precoce și corect al ulcerațiilor pot reduce cu 50-80\% numărul amputațiilor, făcând necesară implementarea unor ghiduri de "bune practici“ la toate nivelele de îngrijire a piciorului diabetic [6].

Obiectivul principal al studiului a fost evaluarea factorilor care influențează durata spitalizării pacienților care au fost internați pentru ulcerații ale piciorului diabetic.

\section{MATERIAL ŞI METODĂ}

Studiul de față este un studiu observațional, retrospectiv, realizat pe pacienții care au fost spitalizați în Clinica Diabet, Nutriție și Boli Metabolice din cadrul Spitalului Clinic Județean de Urgență "Sf. Spiridon", Iași, în perioada 01.01.2007-31.12.2017, având ca motive ale internării ulcerații ale piciorului diabetic. Criteriile de includere pentru colectarea datelor au fost: pacienți cu vârsta > 18 ani, spitalizați în perioada mai sus menționată în Clinica Diabet, Nutriție și Boli Metabolice, prin internare în urgență, programată sau transfer 
din alte clinici, indiferent de tipul de diabet (tip 1, tip 2 sau secundar). Pentru realizarea bazei de date s-au extras date sociodemografice: vârstă, sex, mediu de proveniență (rural / urban), data diagnosticului DZ, din care s-a extras durata DZ; date legate de istoricul bolii: prezența complicațiilor cronice specifice DZ, a bolii cardiovasculare și a bolii renale cronice; parametrii biochimici caracteristici echilibrului glicemic și răspunsului inflamator asociat. Dintre toate clasificările și sistemele de stadializare ale piciorului diabetic am ales să utilizăm în cercetarea de față sistemul San Elian de Scorare a Ulcerațiilor (SEWSS), care include 10 variabile, organizate în 3 categorii: factori anatomici, agravanți și factori ce țin de ulcerație, pentru fiecare item din categorie acordându-se un anumit punctaj. Scopul creării acestui sistem de scorare a fost obținerea unei clasificări omogene a ulcerațiilor piciorului diabetic în trei grade de severitate: ușoară, moderată, severă [7].

Analiza datelor a fost realizată cu ajutorul softului SPSS versiunea 20 (IBM Corp. Released 2011. IBM SPSS Statistics for Windows, Version 20.0. Armonk, NY: IBM Corp). Baza de date a conținut date neparametrice provenind din variabile categoriale (sex, mediu de proveniență, prezența diagnosticelor evaluate, stadializarea piciorului diabetic etc.), cât și date parametrice (vârsta, durata DZ, indicatorii biochimici). Am analizat diferențele în ceea ce privește parametrii continui între două sau mai multe categorii folosind analiza varianței în sens unic (one way ANOVA), pentru variabilele omogene. Pentru a analiza asocierile dintre variabile am folosit regresia liniară și corelațiile Pearson (sau corelațiile Spearman pentru variabilele ordinale). Semnificația statistică a fost definită la o valoare $p<0,05$.

Pentru acest studiu s-a primit anterior inițierii acestuia avizul Comisiei de Etică a Universității de Medicină și Farmacie „Grigore T. Popa“ Iași. Datele de identificare ale participanților nu au fost și nu vor fi folosite în niciun alt scop.

\section{REZULTATE}

Lotul studiat a inclus 659 subiecți, din care 435 bărbați și 224 femei. Media vârstei (ani) \pm deviația standard (DS) a fost de 61,34 $\pm 11,06$ ani, cu un minimum de 19 ani și un maximum de 86 ani. În ceea ce privește distribuția pe sexe a pacienților din studiu, 66\% dintre aceștia erau bărbați, cei mai mulți pacienți provenind din mediul urban, și anume 51,4\% dintre subiecți. Durata medie a bolii în eșantionul analizat a fost de 11,24 $\pm 8,796$ ani. Durata medie de spitalizare a fost de 19,68 $\pm 13,38$ zile, majoritatea pacienților din studiu au fost internați o perioadă de timp < 40 zile. Controlul metabolic a fost precar, 77,5\% prezentând o valoare a hemoglobinei glicate $(\mathrm{HbA} 1 \mathrm{c})$ crescută, peste $7 \%$. În ceea ce privește complicațiile microangiopatice, 65,4\% aveau diagnosticul de retinopatie, iar 31,9\% dintre pacienți au prezentat nefropatie diabetică. Polineuropatia periferică senzitivo-motorie a fost diagnosticată la 93,9\% dintre pacienții din studiu (61,3\% bărbați și 32,6\% femei). Am constatat că arteriopatia obliterantă a membrelor inferioare (AOMI) a fost diagnosticată la 36,4\% dintre pacienții luați în studiu (27,3\% prezentau AOMI stadiul IV). Boala cardiovasculară a fost prezentă la $40,2 \%$ dintre cazuri. În ceea ce privește decompensarea metabolică la internare (prin cetoză sau cetoacidoză), am observat un procent de 14,9\% la lotul total, cu o frecvență mai mare la bărbați $(9,5 \%)$. Am evaluat grupul de studiu, aprofundând datele obținute pe analiza piciorulului diabetic în funcție de criteriile Saint Elian Wound Score System (SEWSS). În ceea ce privește localizarea primară a leziunii, 59,5\% din total au avut localizarea la nivelul falangelor, 30,5\% la nivelul metatarsului și 10\% la nivelul tarsului. Evaluând aspectele topografice ale leziunii, am identificat că $81,5 \%$ au prezentat leziuni la nivel dorsal/plantar, 7,9\% la nivel lateral/medial, iar $10,6 \%$ au prezentat leziuni pe 2 sau mai multe regiuni. În ceea ce privește evaluarea zonelor afectate, am constatat o zonă afectată la 73,9\% dintre cazuri, două zone la $22 \%$ dintre cazuri și trei zone afectate la $4,1 \%$ dintre cazuri. La evaluarea prezenței ischemiei, conform SEWSS, am identificat că doar $36,6 \%$ nu prezentau semne sau simptome de ischemie. Doar un mic procent, de $7 \%$ din totalul subiecților $(2,4 \%$ femei și $4,6 \%$ bărbați), nu a prezentat semne de infecție, 36,3\% dintre cazuri prezentau infecție ușoară, 46,6\% prezentau infecție moderată și 10,3\% infecție severă. La evaluarea adâncimii leziunii, 35,1\% dintre pacienți au avut leziune superficială, 33,8\% - ulcer profund și 31,1\% - leziune ce cuprindea toate straturile anatomice.

$\mathrm{Nu}$ am constatat diferențe semnificative statistic în ceea ce privește durata spitalizării între sexe, mediul de proveniență sau în raport cu complicațiile microangiopatice (tabelul 1). Analizând durata spitalizării în raport cu boala cardiovasculară și boala arterială periferică, am constatat că prezența acestora, și mai ales severitatea arteriopatiei în funcție de stadializarea Leriche-Fontaine, prelungește perioada de spitalizare.

Analizând parametrii de control metabolic, am observat că, în general, controlul glicemic a fost deficitar (HbA1c medie a fost de 9,5\%, iar valoarea medie a glicemiei a fost de $272 \mathrm{mg} / \mathrm{dl}$ ). Analizând apoi markerii statusului inflamator, am constatat valori medii ale $\mathrm{Hb}$ de $12,45 \mathrm{~g} / \mathrm{dl}$, ale $\mathrm{Ht}$ de 37,3\%, valoarea CRP în medie a fost crescută $(6,7 \mathrm{mg} / \mathrm{dl})$, valoarea sideremiei a fost în general scăzută $(44,1 \mathrm{microg} / \mathrm{dl})$. În ceea ce privește statusul renal, valoarea medie a creatininei a fost crescută $(1,6 \mathrm{mg} / \mathrm{dl})$, iar a ratei de filtrare glomerulară a fost în medie scăzută (70,35 ml/min/1,73 mp). Rezultatele analizelor statistice sunt detaliate în tabelul 2 . 
TABEL 1. Media duratei spitalizării separat pe categorii

\begin{tabular}{|c|c|c|c|c|c|c|c|}
\hline & \multirow[t]{2}{*}{ Media } & \multirow[t]{2}{*}{ DS } & \multicolumn{2}{|c|}{$\begin{array}{l}\text { 95\% Interval } \\
\text { Confidență }\end{array}$} & \multirow[t]{2}{*}{ Min. } & \multirow[t]{2}{*}{ Max. } & \multirow[t]{2}{*}{$p$} \\
\hline & & & Lim. Inf. & Lim. Sup. & & & \\
\hline Bărbați & 19,21 & 13,094 & 17,97 & 20,44 & 1 & 98 & \multirow[t]{2}{*}{$>0,05$} \\
\hline Femei & 20,59 & 13,908 & 18,76 & 22,43 & 3 & 87 & \\
\hline Rural & 20,77 & 14,154 & 19,22 & 22,33 & 1 & 98 & \multirow[t]{2}{*}{$>, 05$} \\
\hline Urban & 18,65 & 12,544 & 17,31 & 19,99 & 1 & 87 & \\
\hline Fără retinopatie & 19,54 & 14,007 & 17,71 & 21,36 & 1 & 82 & \multirow[t]{4}{*}{$>, 05$} \\
\hline $\begin{array}{l}\text { retinopatie diabetică } \\
\text { neproliferativă/preproliferativă }\end{array}$ & 20,42 & 13,230 & 18,95 & 21,88 & 3 & 98 & \\
\hline retinopatie diabetică proliferativă & 19,36 & 13,479 & 16,24 & 22,49 & 2 & 69 & \\
\hline $\begin{array}{l}\text { maculopatie/glaucom neovascular } \\
\text { sau alte complicații }\end{array}$ & 15,23 & 9,794 & 12,09 & 18,36 & 3 & 42 & \\
\hline Fără nefropatie & 19,95 & 13,485 & 18,70 & 21,20 & 1 & 98 & \multirow[t]{2}{*}{$>, 05$} \\
\hline Cu nefropatie & 19,10 & 13,171 & 17,30 & 20,89 & 2 & 93 & \\
\hline Fără PNPSM & 17,85 & 13,530 & 13,52 & 22,18 & 1 & 56 & \multirow[t]{2}{*}{$>, 05$} \\
\hline Cu PNPSM & 19,80 & 13,375 & 18,74 & 20,85 & 2 & 98 & \\
\hline Fără BCV & 18,40 & 12,153 & 17,20 & 19,60 & 1 & 98 & \multirow[t]{2}{*}{028} \\
\hline Cu BCV & 21,58 & 14,847 & 19,78 & 23,37 & 2 & 93 & \\
\hline Fără AOMI & 19,13 & 12,634 & 17,92 & 20,34 & 1 & 98 & \multirow[t]{5}{*}{,022 } \\
\hline AOMI stadiul I & 17,22 & 12,306 & 7,76 & 26,68 & 2 & 43 & \\
\hline AOMI stadiul Ila sau IIb & 16,56 & 9,341 & 13,61 & 19,51 & 5 & 46 & \\
\hline AOMI stadiul III & 11,50 & 3,240 & 9,18 & 13,82 & 7 & 18 & \\
\hline AOMI stadiul IV & 22,24 & 15,658 & 19,94 & 24,54 & 1 & 93 & \\
\hline
\end{tabular}

TABEL 2. Descrierea parametrilor biologici la lotul total

\begin{tabular}{|c|c|c|c|c|}
\hline & Min. & Max. & Media & DS \\
\hline Glicemie (mg/dl) & 25 & 1306 & 272,06 & 132,508 \\
\hline HbA1c (\%) & 4,5 & 18,6 & 9,558 & 2,1997 \\
\hline $\mathrm{Hb}(\mathrm{g} / \mathrm{dl})$ & 6,0 & 17,6 & 12,457 & 1,8881 \\
\hline $\mathrm{Ht}(\%)$ & 19,6 & 53,9 & 37,381 & 5,2487 \\
\hline $\mathrm{GA}\left(/ \mathrm{mm}^{3}\right)$ & 1640 & 64100 & 10848,39 & 4897,422 \\
\hline $\mathrm{PMN}\left(/ \mathrm{mm}^{3}\right)$ & 1050 & 91400 & 7820,05 & 6157,944 \\
\hline PMN (\%) & 35,5 & 93,5 & 69,154 & 11,0800 \\
\hline $\operatorname{PLT}\left(/ \mathrm{mm}^{3}\right)$ & 111 & 944000 & 274066,77 & 123356,078 \\
\hline Fibrinogen (mg/dl) & 136 & 1108 & 478,61 & 132,891 \\
\hline $\mathrm{CRP}(\mathrm{mg} / \mathrm{dl})$ & , 0 & 43,4 & 6,729 & 8,4807 \\
\hline Proteine totale $(\mathrm{g} / \mathrm{l})$ & 5 & 94 & 69,86 & 8,463 \\
\hline Albumina (g/l) & 0 & 59,1 & 34,850 & 8,0679 \\
\hline Sideremie (fier seric) (microg/dl) & 7 & 264 & 44,10 & 29,688 \\
\hline Feritina $(\mathrm{ng} / \mathrm{ml})$ & 18 & 2197 & 382,20 & 436,333 \\
\hline Uree $(\mathrm{mg} / \mathrm{dl})$ & 4 & 387 & 52,16 & 32,868 \\
\hline Creatinina (mg/dl) & ,4 & 166,0 & 1,672 & 7,1097 \\
\hline $\mathrm{RA}(\mathrm{mmol} / \mathrm{l})$ & 6 & 33 & 24,48 & 4,011 \\
\hline Rata de filtrare glomerulară (ml/min/1,73 mp) & 5 & 134 & 70,35 & 26,637 \\
\hline
\end{tabular}

La analiza corelației între durata spitalizării și parametrii inflamatori am găsit faptul că aceasta s-a corelat pozitiv cu globulele albe, PMN, CRP și negativ cu hemoglobina, hematocritul, proteinele totale, rezerva alcalină și sideremia (tabelul 3). Nu s-a observat o corelație semnificativă a duratei spitalizării cu Hb A1c.

Evaluarea severității ulcerațiilor cu ajutorul SEWSS (ușoară, moderată și severă), a relevat un procent de
$85,7 \%$ dintre cazuri cu grad moderat, $9 \%$ cazuri cu grad sever și 5,3\% dintre cazuri cu grad ușor, fără diferențe semnificative statistic între sexe $(p=, 625)$. În continuare, am urmărit efectuarea corelațiilor între scorul severității SEWSS și anumiți parametri biologici. Astfel, am găsit corelații puternice inverse între scor și următorii parametri: hemoglobină, hematocrit, proteine totale și sideremie și corelații puternice directe între scor 
TABEL 3. Corelaţia dintre durata spitalizării şi parametrii inflamatori

\begin{tabular}{|c|c|c|c|c|c|c|c|c|c|c|c|c|}
\hline & & $\begin{array}{c}\mathrm{Hb} \\
(\mathrm{g} / \mathrm{dl})\end{array}$ & $\mathrm{Ht}(\%)$ & $\begin{array}{c}\mathrm{GA} \\
\left(/ \mathrm{mm}^{3}\right)\end{array}$ & $\begin{array}{c}\mathrm{PMN} \\
\left(/ \mathrm{mm}^{3}\right)\end{array}$ & $\begin{array}{l}\text { PMN } \\
(\%)\end{array}$ & $\begin{array}{c}\text { Fibrinogen } \\
\text { (mg/dl) }\end{array}$ & $\begin{array}{c}\mathrm{CRP} \\
\text { (mg/dl) }\end{array}$ & $\begin{array}{c}\text { PT } \\
\text { (g/l) }\end{array}$ & $\begin{array}{l}\text { Albumina } \\
(\mathrm{g} / \mathrm{l})\end{array}$ & $\begin{array}{l}\text { Fe seric } \\
(\mu \mathrm{g} / \mathrm{dl})\end{array}$ & $\begin{array}{l}\text { Feritina } \\
\text { (ng/ml) }\end{array}$ \\
\hline \multirow{2}{*}{$\begin{array}{l}\text { Durata } \\
\text { spitalizării }\end{array}$} & $r$ &,$- 109^{* *}$ &,$- 116^{* *}$ &, $227^{* *}$ &, $145^{* *}$ &, $206^{* *}$ & $196^{* *}$ &, $181^{* *}$ &,$- 185^{* *}$ & 132 &,$- 190^{*}$ & ,116 \\
\hline & $p$ & ,005 & ,003 & ,000 & ,000 & ,000 & ,000 & ,001 & ,002 & ,125 & ,011 & 217 \\
\hline
\end{tabular}

TABEL 4. Corelaţia dintre scorul SEWSS şi parametrii inflamatori

\begin{tabular}{|c|c|c|c|c|c|c|c|c|c|c|c|c|c|}
\hline & & $\begin{array}{c}\mathrm{Hb} \\
(\mathrm{g} / \mathrm{dl})\end{array}$ & $\begin{array}{l}\mathrm{Ht} \\
(\%)\end{array}$ & $\begin{array}{c}\mathrm{GA} \\
\left(/ \mathrm{mm}^{3}\right) \\
\end{array}$ & $\begin{array}{c}\mathrm{PMN} \\
\left(/ \mathrm{mm}^{3}\right)\end{array}$ & $\begin{array}{c}\text { PMN } \\
(\%)\end{array}$ & $\begin{array}{c}\text { PLT } \\
\left(/ \mathrm{mm}^{3}\right)\end{array}$ & $\begin{array}{c}\text { Fibrinogen } \\
(\mathrm{mg} / \mathrm{dl})\end{array}$ & $\begin{array}{c}\text { CRP } \\
(\mathrm{mg} / \mathrm{dl})\end{array}$ & $\begin{array}{l}\text { PT } \\
(\mathrm{g} / \mathrm{l})\end{array}$ & $\begin{array}{c}\text { Albumina } \\
(\mathrm{g} / \mathrm{l})\end{array}$ & $\begin{array}{c}\text { Fe seric } \\
\text { (microg/dl) }\end{array}$ & $\begin{array}{l}\text { Feritina } \\
(\mathrm{ng} / \mathrm{ml})\end{array}$ \\
\hline & $r$ &,$- 229^{* *}$ &,$- 213^{* *}$ &, $277^{* *}$ & ,269** & ,317** &, $141^{* *}$ &, $273^{* *}$ & ,229** &,$- 223^{* *}$ & 110 &,$- 320^{* *}$ & ,195* \\
\hline SEWSS & $p$ & 000 & ,000 & ,000 & ,000 & ,000 & ,000 & ,000 & ,000 & ,000 & 201 & ,000 & ,038 \\
\hline
\end{tabular}

și următorii parametri: leucocite, PMN, fibrinogen, CRP (tabelul 4).

Durata spitalizării s-a corelat semnificativ cu gradarea realizată de scorul SEWSS ( $r=0,272, p<0,001)$. În ceea ce privește durata de spitalizare în raport cu severitatea infecției clasificată după SEWSS, am remarcat o diferență semnificativă statistic, și anume cei cu infecție severă au avut o durată mai lungă de spitalizare $(p<0,001)$. Având în vedere corelațiile obținute dintre severitatea leziunii, evaluată prin scorul SEWSS, parametrii inflamatori și durata internării, am evaluat ipoteza predicției duratei internării în funcție de scorul de severitate al leziunii și amplitudinea răspunsului inflamator (tabelele 5, 6). Severitatea leziunii a prezis durata spitalizării independent de parametrii biologici, dar și de vârsta pacienților, controlul glicemiei sau de durata bolii (Tabelul 6).
TABEL 5. Modele de predicție a duratei de spitalizare

\begin{tabular}{|l|c|c|r|r|r|}
\hline Model & $\mathbf{R}$ & $\mathbf{R}^{\mathbf{2}}$ & $\begin{array}{r}\mathbf{R}^{\mathbf{2}} \\
\text { ajustat }\end{array}$ & $\begin{array}{c}\text { Eroarea } \\
\text { standard }\end{array}$ & $\begin{array}{c}\mathbf{p} \\
\text { (ANOVA) }\end{array}$ \\
\hline 1 &, $243^{\mathrm{a}}$ &, 059 &, 051 & 15,526 &, 006 \\
\hline 2 &, $350^{\mathrm{b}}$ &, 122 &, 070 & 15,375 &, 029 \\
\hline 3 &, $364^{\mathrm{c}}$ &, 133 &, 065 & 15,416 &, 051 \\
\hline
\end{tabular}

a. Predictor: (Constant), Scor SEWSS

b. Predictori: (Constant), Scor SEWSS, RA (mmol/I), HbA1c (\%),

$\operatorname{CRP}(\mathrm{mg} / \mathrm{dl}), \mathrm{Hb}(\mathrm{g} / \mathrm{dl}), \mathrm{GA}\left(/ \mathrm{mm}^{3}\right)$, Fibrinogen $(\mathrm{mg} / \mathrm{dl})$

c. Predictori: (Constant), Scor SEWSS, RA (mmol/I), HbA1c (\%),

CRP $(m g / d l), H b(g / d l), G A\left(/ m m^{3}\right)$, Fibrinogen $(m g / d l)$, Vârstãa Durata diabetului

d. Variabila depndentă: Durata spitalizãrii

\section{DISCUŢII}

În literatură au fost publicate numeroase date care atrag atenția asupra asocierii dintre piciorul diabetic,

TABEL 6. Sumarul regresiei duratei spitalizării

\begin{tabular}{|c|c|c|c|c|c|c|}
\hline \multirow{2}{*}{\multicolumn{2}{|c|}{ Model }} & \multicolumn{2}{|c|}{$\begin{array}{c}\text { Coeficienți } \\
\text { nestandardizați }\end{array}$} & \multirow{3}{*}{\begin{tabular}{|c|}
$\begin{array}{c}\text { Coeficienți } \\
\text { standardizați }\end{array}$ \\
\multicolumn{2}{|c|}{ Beta } \\
$\mathbf{2 4 3}$ \\
\end{tabular}} & \multirow{3}{*}{$\begin{array}{c}\mathrm{t} \\
2,775\end{array}$} & \multirow{3}{*}{$\begin{array}{l}\text { Sig. } \\
, 006 \\
\end{array}$} \\
\hline & & \multirow{2}{*}{\begin{tabular}{|l|}
$B$ \\
1,174 \\
\end{tabular}} & \multirow{2}{*}{$\begin{array}{r}\text { Std. Error } \\
\mathbf{4 2 3} \\
\end{array}$} & & & \\
\hline 1 & Scor SEWSS & & & & & \\
\hline \multirow[t]{7}{*}{2} & Scor SEWSS & 1,046 & ,476 & ,216 & 2,197 & ,030 \\
\hline & $\mathrm{Hb}(\mathrm{g} / \mathrm{dl})$ &,- 068 & ,770 &,- 008 &,- 088 & ,930 \\
\hline & $\mathrm{GA}\left(/ \mathrm{mm}^{3}\right)$ & ,001 & , 000 & ,201 & 1,837 & 069 \\
\hline & Fibrinogen (mg/dl) &,- 019 & ,016 &,- 136 & $-1,167$ & ,246 \\
\hline & CRP (mg/dl) &, 020 & ,223 & ,011 & ,089 & ,929 \\
\hline & HbA1c (\%) & ,125 & ,700 & 016 & ,178 & ,859 \\
\hline & $\mathrm{RA}(\mathrm{mmol} / \mathrm{l})$ &,- 499 & ,336 &,- 134 & $-1,484$ & 141 \\
\hline \multirow[t]{9}{*}{3} & Scor SEWSS & 1,059 & ,479 & ,219 & 2,213 & ,029 \\
\hline & $\mathrm{Hb}(\mathrm{g} / \mathrm{dl})$ & ,247 & 817 & ,031 & ,302 & ,763 \\
\hline & $\mathrm{GA}\left(/ \mathrm{mm}^{3}\right)$ & ,001 &, 000 & ,206 & 1,873 & ,064 \\
\hline & Fibrinogen (mg/dl) &,- 025 &, 017 &,- 181 & $-1,469$ & ,144 \\
\hline & CRP (mg/dl) & ,056 & ,226 &, 030 & ,249 & ,804 \\
\hline & HbA1c (\%) & ,021 & ,753 & ,003 & ,028 & ,978 \\
\hline & $\mathrm{RA}(\mathrm{mmol} / \mathrm{l})$ &,- 580 & ,345 &,- 156 & $-1,680$ & ,096 \\
\hline & Vârstã &,- 046 & ,139 &,- 032 &,- 335 & ,738 \\
\hline & Durata diabetului & ,214 & , 185 & ,113 & 1,153 & ,251 \\
\hline
\end{tabular}


evenimentele cardiovasculare și mortalitatea crescută în rândul pacienților cu diabet. Piciorul diabetic este considerat un predictor al evenimentelor cardiovasculare și al mortalității, ca urmare a intervenției unor mecanisme fiziiopatologice comune. S-a observat o asociere puternică între nivelul crescut al cistatinei C (marker al inflamației, dar și al funcției renale), mortalitatea prin boală cardiovasculară și severitatea ulcerației piciorului diabetic [8-11]. Identificarea timpurie și gestionarea multidisciplinară a ulcerațiilor piciorului diabetic sunt esențiale pentru a reduce morbiditatea și mortalitatea semnificativă la acești pacienți complecși [12].

O echipă condusă de Bobircă și colab. a analizat 188 de pacienți care prezentau predominant leziuni arteriopatice ale piciorului diabetic. Luând în considerare tipul leziunii piciorului, majoritatea pacienților au avut diagnosticul de gangrenă umedă a degetelor de la picioare $(51,06 \%)$, urmată de gangrenă ischemică a degetelor de la picioare $(40,4 \%)$. Intervențiile chirurgicale efectuate la aceste tipuri de leziuni în $73,9 \%$ dintre cazuri au constat în amputări minore (amputarea transmetatarsiană a degetului/degetelor de la picioare/picior) [13]. Algoritmul de tratament dezvoltat ca rezultat al acestui studiu reprezintă o soluție de tratament fezabilă pentru patologia piciorului diabetic predominant arteriopatic.

În lotul studiat de către noi, am analizat repartiția cazurilor în funcție de clasificarea infecției conform SEWSS, și am constatat că 36,3\% dintre cazuri prezentau infecție ușoară, 46,6\% dintre pacienți prezentau infecție moderată și 10,3\% infecție severă, restul cazurilor, un procent de $6,8 \%$ neprezentând infecție asociată.

Numeroase cercetări au fost efectuate pentru a identifica markerii biologici ai severității și evoluției ulcerațiilor piciorului diabetic. În acest sens, Todorova și colab. au comparat eficacitatea procalcitoninei (PCT) și a proteinei $\mathrm{C}$ reactive cu sensibilitate ridicată (hsCRP) ca biomarkeri diagnostici la pacienții cu DZ și infecții ușoare până la moderate ale piciorului diabetic. Rezultatele lor au arătat că valoarea hsCRP seric, numărul globulelor albe și viteza de sedimentare a hematiilor au fost semnificativ mai mari în grupul pacienților cu picior diabetic cu infecție, în comparație cu grupurile de pacienți cu ulcerație fără infecție și pacienți diabetici fără ulcerație. [14].

Durata medie de spitalizare în lotul nostru a fost de $19,68 \pm 13,38$ zile, majoritatea pacienților din studiu fiind internați o perioadă de timp $<40$ zile, fără a exista diferențe semnificative statistic în ceea ce privește durata spitalizării în funcție de gen.

Analizând durata spitalizării în raport cu boala cardiovasculară și boala arterială periferică, am constatat că prezența acestora, și mai ales severitatea arteriopatiei în funcție de stadializarea Leriche-Fontaine, prelungește perioada de spitalizare. La compararea duratei de spitalizare în relație cu neuropatia periferică nu am găsit diferențe semnificative statistic. În ceea ce privește durata de spitalizare în raport cu severitatea infecției clasificată după SEWSS, am remarcat o diferență semnificativă statistic, și anume cei cu infecție severă au avut o durată mai lungă de spitalizare $(p<0,001)$. Durata spitalizării s-a corelat pozitiv cu parametrii statusului inflamator și negativ $\mathrm{cu} \mathrm{Hb}, \mathrm{Ht}$, proteinele totale și fierul seric.

Ulcerele piciorului diabetic reprezintă una dintre cele mai debilitante complicații ale DZ, putând duce la amputații, mai mult sau mai puțin limitate, sau chiar deces. Diagnosticul tardiv de picior diabetic s-a asociat cu $10,8 \%$ costuri mai ridicate și cu $12,1 \%$ durata mai mare de spitalizare [15]. Tratamentul și gestionarea ulcerelor piciorului diabetic sunt printre cele mai critice provocări pentru pacienți și familiile lor, dar și pentru echipa medicală, fiind necesară o îngrijire multimodală și tratament multidisciplinar [16]. Concomitent, este necesară identificarea factorilor de risc pentru apariția complicațiilor piciorului diabetic. În acest sens, un grup de autori au realizat un studiu retrospectiv de cohortă pe 3002 pacienți cu DZ tip 2 cu vârsta $\geq 18$ ani, fără complicații anterioare ale piciorului [17]. Datele au fost colectate în intervalul 2006-2017 într-un departament spitalicesc austriac specializat pentru pacienții diabetici. Factorii de risc semnificativi pentru complicațiile piciorului au fost: vârsta la diagnostic > 70 de ani, sexul masculin, neuropatia, boala arterială periferică, hipertensiunea arterial > 10 ani după diagnostic și $\mathrm{HbA1c}>9 \%$ [17].

Una dintre limitările importante ale acestui studiu se referă la faptul că este un studiu observațional, desfășurat într-un singur centru, fiind necesare studii ulterioare pentru a evalua posibilitatea de a influența pozitiv durata de spitalizare și evoluția ulcerațiilor piciorului diabetic. Punctele tari ale studiului sunt reprezentate de perioada lungă de analiză (10 ani), numărul mare de pacienți incluși în studiu și multitudinea de parametric evaluați.

\section{CONCLUZII}

Studiul efectuat a urmărit evaluarea factorilor care pot influența gravitatea și evoluția ulcerațiilor piciorului diabetic, evaluată indirect prin durata spitalizării. Adresarea la internare în stadii lezionale avansate s-a asociat cu creșterea duratei de spitalizarea, sugerând astfel necesitatea educației pacienților și a screeningului activ al piciorului diabetic pentru ameliorarea prognosticului și reducerea costurilor asociate îngrijirii acestor pacienți. 


\section{BIBLIOGRAFIE}

1. Singh N, Armstrong DG, Lipsky BA. Preventing foot ulcers in patients with diabetes. JAMA. 2005 Jan 12;293(2):217-28

2. Boulton AJ, Vileikyte L, Ragnarson-Tennvall $\mathrm{G}$, Apelqvist J. The global burden of diabetic foot disease. Lancet. 2005 Nov 12;366(9498):1719-24.

3. Lepäntalo M, Apelqvist J, Setacci C, Ricco JB, de Donato G, Becker F, et al. Chapter V: Diabetic foot. Eur J Vasc Endovasc Surg. 2011 Dec;42 Suppl 2:S60-74.

4. Apelqvist J, Ragnarson-Tennvall G, Persson $U$, Larsson J. Diabetic foot ulcers in a multidisciplinary setting. An economic analysis of primary healing and healing with amputation. J Intern Med. 1994 May;235(5):463-71.

5. Prompers L, Huijberts $M$, Schaper $N$, Apelqvist J, Bakker K, Edmonds M, et al. Resource utilisation and costs associated with the treatment of diabetic foot ulcers. Prospective data from the Eurodiale Study. Diabetologia. 2008 Oct;51(10):1826-34.

6. Reiber GE, Lemaster JW. Epidemiology and economic impact of foot ulcers and amputations in people with diabetes. In: Bowker JH, Pfeifer MA (eds.). Levin and O'Neal's The Diabetic Foot. 7th Edition. Mosby Inc., an affiliate of Elsevier; 2008:3-28.

7. Martínez-De Jesús FR. A checklist system to score healing progress of diabetic foot ulcers. Int J Low Extrem Wounds. 2010 Jun;9(2):74-83.

8. Pop-Busui R, Ang L, Holmes C, Gallagher K, Feldman EL. Inflammation as a Therapeutic Target for Diabetic Neuropathies. Curr Diab Rep. 2016 Mar;16(3):29.

9. Lanting SM, Twigg SM, Johnson NA, Baker MK, Caterson ID, Chuter VH. Non-invasive lower limb small arterial measures co-segregate strongly with foot complications in people with diabetes. J Diabetes Complications. 2017 Mar;31(3):589-593.

10. Shlipak MG, Sarnak MJ, Katz R, Fried LF, Seliger SL, Newman AB, Siscovick DS, Stehman-Breen C. Cystatin $C$ and the risk of death and cardiovascular events among elderly persons. N Engl J Med. 2005 May 19;352(20):2049-60.

11. Ogawa Y, Goto T, Tamasawa N, Matsui J, Tando Y, Sugimoto K, Tomotsune K, Kimura M, Yasujima M, Suda T. Serum cystatin C in diabetic patients. Not only an indicator for renal dysfunction in patients with overt nephropathy but also a predictor for cardiovascular events in patients without nephropathy. Diabetes Res Clin Pract. 2008 Feb;79(2):357-61.

12. Rosi LM, Jones AS, Topliss DJ, Bach LA. Demographics and outcomes of inpatients with diabetic foot ulcers treated conservatively and surgically in a metropolitan hospital network. Diabetes Res Clin Pract. 2021 Apr 16;175:108821.

13. Bobircă $F$, Bobircă $A$, Bordianu $A$, Jauca $C$, Georgescu D, Radu R, Pătraşcu T. Current Surgical Approach in the Pathology of the Arteriopathic Predominant Diabetic Foot. Chirurgia (Bucur). 2018 SeptOct;113(5):625-633.

14. Todorova AS, Dimova RB, Chakarova NY, Serdarova MS, Grozeva GG, Georgiev GK, Tankova TI. Comparative Evaluation of the Diagnostic Value of Procalcitonin and hsCRP for the Presence of Mild-to-Moderate Diabetic Foot Infections. Int J Low Extrem Wounds. 2021 Apr 28:15347346211011849.

15. Labovitz JM, Shapiro JM, Satterfield VK, Smith NT. Excess Cost and Healthcare Resources Associated With Delayed Diagnosis of Charcot Foot. J Foot Ankle Surg. 2018 Sep-Oct;57(5):952-956.

16. Parizad N, Hajimohammadi K, Goli R. Surgical debridement, maggot therapy, negative pressure wound therapy, and silver foam dressing revive hope for patients with diabetic foot ulcer: A case report. Int J Surg Case Rep. 2021 May;82:105931.

17. Rossboth S, Rossboth B, Schoenherr H, Ciardi C, Lechleitner M, Oberaigner W. Diabetic foot complications-lessons learned from real-world data derived from a specialized Austrian hospital. Wien Klin Wochenschr. 2021 May 3.

Conflict of interest: none declared Financial support: none declared 